\title{
Consumers, farmers and the future of New Zealand hill country farming
}

\author{
A.K. McDERMOTT ${ }^{1}$ and F.G. SCRIMGEOUR ${ }^{2}$ \\ ${ }^{I}$ ANZCO Foods Ltd, PO Box 39-186, Harewood, Christchurch 8053, New Zealand \\ ${ }^{2}$ University of Waikato, Private Bag 3105, Hamilton 3240, New Zealand
}

alan.mcdermott@anzcofoods.com

\begin{abstract}
The future of hill country farmers depends on constructive engagements with international consumers and domestic values and politics. Antifragility, being at worst unharmed by or benefiting from stresses or shocks, involves both reducing system downside and maximising the upside potential. Antifragility is enhanced by farmers selecting partners with which they align in transparent relationships. Farmers should consider integration or collaboration rather than selfsufficiency. Maintaining an element of flexibility within the farm system is also essential. In addressing the market it is not appropriate to focus on the average consumer. New Zealand producers should target those who care about what is good for them with what is good for the world and good quality; listen to them and deliver what they want. Delivering on what is wanted requires farmers to "farm like they are watching you". They are. Farmers and companies need to be able to verify what they claim and celebrate an honest story.
\end{abstract}

Keywords: antifragility, consumers, flexibility, honesty, quality, transparency

\section{Key messages}

- Establish aligned, transparent partnerships with other farmers, processors and customers to enhance antifragility

- Focus on delivering to specific targeted customers and consumers, not an average position; but maintain a flexible element in the farm system

- Ensure quality and raising claims can be verified and celebrate an honest story.

\section{Introduction}

New Zealand agriculture is fortunately positioned. It is based upon a broadly temperate climate and fertile soils, with largely adequate water through rainfall or readily available irrigation. Perennial forages grow for much of the year, although seasonally, and deficits are readily met by forage crops or conserved feed. New Zealand farming has historically been low-cost and has little need to house livestock. Further, New Zealand is an island nation, so far ensuring freedom from numerous potentially crippling pests and diseases - isolation acts as a barrier. Without doubt, pastoral farming in New
Zealand has achieved impressive rates of productivity improvement (Burtt 2015).

Despite the advantageous situation, hill country farming faces numerous challenges. The research community has consistently worked to address core biophysical science understanding, farming system design and agricultural policy challenges. Efforts have also been made to address sociological and environmental issues that had received limited attention in the past. In addition, a key challenge to sustaining antifragile hill country farming is securing enduring relationships with meat processors and meat customers. Antifragile systems are those that are at worst unharmed by or benefit from stresses or shocks (Taleb 2012). Furthermore, the opportunities associated with wool should not be forgotten. Experience shows New Zealand is generally well perceived by customers and consumers. Although they may know little about New Zealand, "Made in New Zealand" is not seen as something to be afraid of. New Zealand is seen as green, welcoming and open. "The New Zealand Story" ("Open spaces, open hearts, open minds") (New Zealand Government 2015) is broadly credible. However, the reliance on the overarching New Zealand story is that should anybody or any sector stumble, all sectors may end up falling together.

Has New Zealand's fortunate place in the world resulted in agriculture here becoming relatively unprepared for the future in which operational excellence and partnerships are essential? Is New Zealand agriculture running on complacency and opportunism? Does it have the required culture for long term success?

\section{Consumers}

Consumers do care about production practices. In most developed markets, such as UK, EU, US, and Japan, they expect not to have to worry about where or how food is produced or what impact might be had on the environment (Saunders et al. 2013). The majority could be considered to be wilfully ignorant. Mostly, they are right to not worry about such things, but things do go wrong from a food safety, animal welfare or environmental perspective. The New Zealand meat industry has been remarkably fortunate in this respect; the dairy industry, a little less so. 
However, in developing markets, such as China, India, and the Middle East, where consumers have long been incorrectly considered to be unconcerned by such ethical considerations, these are becoming increasingly of primary concern (Saunders et al. 2013). These consumers want to know that food products were produced safely and with due care for the environment - that is how they define quality. Importantly, these consumers are prepared to pay for these attributes, because they do not expect them in products produced in their own countries - they live in low trust environments. Because of their low trust levels, these consumers may require even more stringent standards and checks than New Zealand's other customers.

Consumers everywhere are focusing on four key aspects - "good for me", "good for the world", "good quality" and the ever-present "good value".

The key areas in addressing "good for me" are product integrity, safety and naturalness such as being antibiotic-free, grass-fed and hormone-free. Consumers are seeking reassurance on all of these attributes and full traceability. The major new trend in 2015 was towards being GM-free, with the Non-GMO Project, a US-based non-government organisation, taking a lead role in verification. Organics is also continuing to trend upwards. Natural and organic beef consumption in the US increased more than $50 \%$ in 2 years from less than $4 \%$ to more than $6 \%$ of purchases (FreshLook Marketing 2015).

The key concerns in addressing "good for the world" are animal welfare, ethical production and environmental stewardship. The drive to support local food producers will not cease; it makes consumers feel they are making a difference to the world, socially and environmentally whether they are or not.

Whilst some consumers are prepared to give up a little with respect to product attributes to achieve other outcomes for society, the environment or their own wellbeing, most require "good quality" as well. They expect variety and choice of cuts and pack sizes, while also expecting consistency in availability. Consumers have far from robust knowledge of the farm or the seasons. Discussions with customers indicate many Europeans, for example, believe it is green and warm all year round in New Zealand - the land of milk and honey!

Consumers, especially those with an interest in healthy eating, are label readers and require information on nutrition and health (Grunert et al. 2010). They are discerning and take time to learn about products and how they are produced (Hartman Group 2015). The widespread development and availability of information and communication technologies means that consumers are now connected and tech-savvy and through social media can readily share ideas, news and knowledge with the capacity to rapidly and dramatically enhance or destroy a product or company's image. These shoppers are cynical, having been exposed to too many logos that mean little. We better have substance and integrity in what we do, what we say we do, and be able to prove it immediately.

"Good value" has always been a focus for consumers, and is relative with some consumers being prepared to pay more for similar products with more of the "good for me", "good for the world" and "good quality" attributes. However, the recent global economic situation has encouraged shoppers to become more conscious of food cost and waste with frugality becoming the new order. Retailers are seeing shoppers using different stores for different items and bargain hunting, while other shoppers have embraced buying groceries online for convenience.

\section{Retailers as regulators}

The pathway to consumers is via retailers and restaurants. It is crucial their role in the system is understood. Retailers see themselves and are seen by consumers as protectors of food system integrity with respect to food safety, animal welfare, human rights and the environment (Food Marketing Institute 2015). Retailers are responding, and continuing to develop standards to protect their reputations and brands, and to demonstrate to consumers they are taking these issues seriously. They want to report to their stakeholders on the performance of their supply chains. Retailers want to achieve top rankings in various competitions and awards in an attempt to demonstrate and prove they are more ethical than their competitors. A recent development has been the involvement with nongovernment organisations to give retailers greater credibility and to ensure they are well directed and in touch with consumer sentiment and leading 'ethical knowledge'. Many global retailers have engaged NonGovernment Organisations (NGOs) to assist in their procurement strategies. These NGOs are helping define what is considered to be an environmentally sustainable and ethical product, and production systems.

There is strong demand for products that can provide the above attributes with integrity and provenance, which allows retailers to tell a story. In most cases, retailers will want to own the brand and tell the story themselves. New Zealand needs to be providing products that allow these stories to be told, and the evidence to support these claims. It is the retailer that is the trusted brand when it comes to fresh foods such as meat and produce. It is their name above the door, and they will do everything to protect that brand; that is their intangible value. "Horsegate" provides a valuable lesson in what happens when a company does not live up to its or its customers' standards and expectations. Retailers who do not want sensational headlines are 
working hard to avoid them. McDonald's is working with WWF. Sainsbury works with RSPCA Freedom Foods and Greenpeace. Waitrose is partnering with universities to support sustainable agriculture, and is the only retailer that insists all its British growers adopt the LEAF standard (Linking Environment and Farming), an independent charitable organisation that helps farmers improve business performance, lower environmental impacts, conserve the British countryside for future generations and strengthen links with the public. In New Zealand, Waitrose lamb producers have adopted a similar programme.

Retailer standards are becoming increasingly challenging and onerous. New Zealand suppliers and processors need to ensure that retailers' standards make sense in every sense - environmentally, biologically, animal welfare, food safety, and health and safetywise. Regardless, the message is "Farm like they are watching you, because they are!"

\section{Processors and marketers as business partners}

Hill country farms access consumers via the processing and marketing companies that supply retailers. Farmers need these firms to perform to a high standard to secure their own goals. These firms struggle to achieve their aspirations in the face of supply side challenges. Most large processors outside of agriculture reduce their number of suppliers to manage quality and throughput. However, meat companies must cope with a substantial proportion of farmers who adjust their supply decisions at short notice. This challenge combined with high levels of capital investment relative to throughput hinders investment in enhancing processing and market development. Over recent years, dairy farmers have used large amounts of supplementary feed to sustain production and the seasonality of the milk flow is changing. Hill country farmers in collaboration with other farmers will often have the potential to substantially adjust feeding regimes to improve productivity in the processing sector, and indeed their own businesses. Not only do such alliances have the potential to boost total output; they can offer farmers the chance to minimise downside and benefit from upside (McDermott \& Shadbolt 1998), creating antifragility.

\section{Public as regulators}

Farm practice is not only being challenged by consumers. There is increasing pressure, primarily from domestic sources, to implement higher environmental standards. This pressure is being exerted by regional councils and various NGOs for the environment's sake and for societal and recreational benefits. There is also growing attention on animal welfare from New Zealand authorities.
The New Zealand public is watching us. There are people and organisations that want nothing more than for us to stumble, providing further reason to promote their particular world views or philosophies. NGOs and other interest groups are funded by donations. Sensational headlines help drive this funding model. These groups are often proactively seeking to create and orchestrate such headlines. Not providing the basis for a sensational headline is the requirement to avoid creating fragility.

Regulators are also exploring how to allocate the full cost of food production to farmers. This will have real consequences on profitability and on asset values. Extra demands placed on landowners will not only affect farm practice, production and costs. They will also impact land values.

\section{Threats or maybe opportunities?}

Sheep and beef farmers face numerous additional domestic challenges such as continuing land use change on versatile land, and this will impact the options available to hill farmers. There appears to be no end to the current over-capacity in the meat processing/ exporting sector and New Zealand has one of the more volatile exchange rates. Opportunistic behaviour along the supply chain continues to erode value, create volatility and ensure fragility. Furthermore, red meat is already a highly-priced food item, and will never, nor should it, compete with monogastric or aquaculture protein production. The inefficiency of the rumen may pale in comparison to lab-based protein production (beyond meat) - which will become commercial in the medium term and address many of the environmental impacts; already available insect protein; or potentially futuristic 3D-printing of food. Not only do these technologies impact the full cost of production, but they shorten the supply chain with the potential to devolve food production similarly to home generation of electricity. In addition, there is the question of whether to embrace molecular technologies for use in New Zealand, on which a choice must urgently be made.

\section{Preparing for the future}

Despite the challenges, multiple steps can be taken to increase the resilience of hill country farming.

\section{Supplying market niches}

While some niches appreciate the true cost or value of food, and are prepared to pay for it, others are focused on wellness or convenience. Religious and philosophical niches provide an opportunity. New Zealand needs to look where people pay the most for their food. Switzerland, Norway and Hong Kong (USDA 2014) are examples of markets with the proven capacity to pay for it, offering antifragility opportunities. New 
Zealand cannot focus on average consumers. However, consumers are a little reluctant to spend a lot more on food, and customers even less so. Consumers have become more frugal, and retailers have trained them to bargain hunt. The proportion of disposable income spent on food continues to decline, to as low as $7 \%$ in some developed nations (USDA 2014). Although some consumers will occasionally 'splash out', the farmers' proportion of the final price does not tend to increase as the value of the finished product increases (McDermott et al. 2006), because to generate these higher prices the supply chain incurs more costs. Integrity pays, but it also costs.

\section{Total quality management}

Doing the right thing with integrity pays. New Zealand farmers are typically not good at recording what they have done. If it is not written down, it did not happen ... if it cannot be verified ... it did not happen. Customers are getting closer to our businesses. Customers and consumers want confidence. Digital tools will simplify and streamline the required record keeping and data capture, and make it available and useful for management decisions. The vast majority of customers, especially target customers, are seeking to buy beef and lamb farmed to a standard. Customers want to make label claims. Farmers do know their systems and their ecosystems better than their customers do; but listen to customers. In New Zealand, farmers are largely doing the right things. Granted there are some challenges around water, phosphorous, sediment and in hill country there is a need to do more to address resource use efficiency. New Zealand needs to have a national standard that everybody subscribes to. We are only as good as the worst of us. The Red Meat Profit Partnership (RMPP) will soon deliver such a farm assurance standard for sheep, beef and deer farmers. It will open up niches. Will we get higher prices as a result? Not that often - consumers expect this, and globally consumers have become more frugal. Why should they pay for an ecosystem service, such as a river you can swim in, when they already pay for such things through their own taxes? However, it does form part of the value package, and preserves positioning, giving consumers another reason to keep paying a premium and to keep buying, becoming less fragile. An example is a Japanese restaurant chain with 300 stores which specifies, as well as carcass traits, a list of chemicals that cannot be used by supplying farmers because they are carcinogenic. The customer is concerned about the health of New Zealand farmers and the eco-toxicity of the chemicals. They also want safe and healthy beef to make their hamburgers. During the BSE crisis, sales in these restaurants actually grew while their competitors collapsed.

\section{Building commercial relationships}

Future success crucially depends on farmers picking a partner, and being aligned with and transparent to them. The findings from the RMPP segmentation survey carried out by UMR Research highlighted the opportunity to build stronger, closer relationships between producers and processors (UMR 2014). The level of transparency will depend upon the extent and openness of the relationship established. Transparency requires direct relationships between customers, processors and farmers, and could eventually involve transparency around farm, processing and marketing costs as well as revenues and the associated margins. Improved levels of transparency will facilitate and require benchmarking at all stages of the supply chain, encouraging a focus on best practice, continuous improvement and fairness. It also requires a different approach along the supply chain with all parties having to be accountable for their role in creating and delivering value. Transparent supply chains involve farming and processing for customers, and therefore require different behaviour. For example, drafting animals well in advance will be required to provide accurate forward knowledge of livestock, and the opportunity to fill any supply gaps. Failure to deliver is not an option. This requires disciplined monitoring and planning on farm. It also requires at least one element of the farm system or stock class to be quite flexible and available as a buffer against the various shocks and stressors. Similarly, discipline is required further down the chain. Timely quality feedback from processors to farmers is essential to enable responsiveness and improvement. Information must be shared rather than held as a source of power and opportunism. To ensure longevity and satisfaction, partners require aligned motivation, values and cultures, and a blend of trust and both social and formal control mechanisms. They must understand each other. It will take time. Such relationships reduce fragility, actually creating antifragility, and are likely to enhance production efficiency.

\section{Collaboration for upside exploitation and downside minimisation}

Hill country farmers have new opportunities both on their own properties and in collaboration with other farmers. New forages are allowing hill country farmers to finish livestock more readily, but is this the right approach? Yes, it probably does reduce market risk, and climate risk, but is the upside being maximised and are these farm systems becoming too managerially complex? Could these risks be managed differently through vertical integration or alliances with finishers on versatile land while growing the upside and minimising complexity? Could that hill country feed be better and more profitably used to increase reproductive 
performance further to carry more breeding stock so as to increase the total progeny, the key driver of profitability on these farms? Contrarily, the current approach of self-containment may be seen by customers as providing the livestock better welfare outcomes, but they still need to pay for it, and experience suggests this upside is limited by the price of alternatives. Farmers do not have a strong history of working together in this way, tending to operate more opportunistically, if not as adversaries.

\section{Customer satisfaction}

Deliver what your customer wants, always. And what your customer's customer wants. If consumers decide they do not like practices such as tail docking, castration or ear marking, find an alternative to achieve the outcome desired. However, there is a role for customer and consumer education. Any such messages need to be simple without ambiguity, something which is often difficult with complex issues such as animal welfare and the environment. This should always be attempted to at least build an understanding of all perspectives.

If the strategy is to produce more store animals for a specialist finisher through an alliance or vertical integration, then specifications must still exist for those animals at the time they are transferred. There need to be agreed specifications or formal controls at each point along the supply chain, and this includes timing of supply. Operational excellence is required together with excellent communication along the supply chain to achieve this. Considerable focus must also be placed upon the eating experience had by the consumer. Being good on average means there is still variation. It is always the variation that catches you out. Few farmers should commit all of their output to tightly specified supply chains; rather instead retain an element of flexibility to reduce the variation delivered to those customers.

\section{Ongoing investment in reputation}

Tell the story, and tell it honestly. The food industry must proactively engage with the public and consumers, both directly and through retailers. There must be a collective effort to ensure standards are raised and normalised. Integrity is essential. High performance must be celebrated and promoted. Historically, there has been limited celebration or promotion of what has been achieved. Imagine a farming award story leading the news at $6 \mathrm{pm}$ ! Such proactivity will be good for customer access and also in the eyes of the New Zealand public. This must not be green wash; that would be fragile. Honesty builds social capital and is a genuine comparative advantage.

\section{REFERENCES}

Burt, A. 2015. Domestic Trends and Measuring Progress against the Red Meat Sector Strategy. Presentation to Red Meat Sector Conference 2015, Nelson.

Food Marketing Institute. 2015. U.S. Grocery Shopper Trends 2015 Executive Summary. Arlington: Food Marketing Institute. $21 \mathrm{pp}$.

FreshLook Marketing LLC. http://igrow.org/livestock/ beef/nutritional-value-of-organic-vs.-conventionalbeef Accessed 2 November 2015.

Grunert, K.G.; Wills, J.M.; Fernandex-Celemin, L. 2010. Nutrition knowledge, and use and understanding of nutrition information on food labels among consumers in the UK. Appetite 55: 177-189.

Hartman Group. 2015. Animal Proteins: The ConsumerDriven Demand for Transparency. Available at: http://hartbeat.hartman-group.com/hartbeat/613/ animal-proteins-the-consumer-driven-demand-fortransparency. Downloaded 22 January 2016.

McDermott, A.K.; Shadbolt, N.M. 1998. Strategic alliances for competitive viability in lamb production systems: Impact upon risks and returns. pp. 70-79. In: Proceedings of the Annual Conference of the New Zealand Agricultural and Resource Economics Society (Discussion Paper No. 146), Blenheim, NZ, Lincoln, NZ: Agribusiness and Economics Research Unit, Lincoln University.

McDermott, A.K.; Sumner, R.M.W.; Scobie, D.R. 2006. Options for change within the wool supply chain. Proceedings of the New Zealand Society of Animal Production 66: 213-219.

New Zealand Government. 2015. The New Zealand Story. Available at http://www.nzstory.govt.nz/whatis-nz-story. Accessed 21 January 2016.

Saunders, C.; Guenther, M.; Tait, P.; Saunders, J. 2013. Assessing consumer preferences and willingness to pay for NZ food attributes in China, India and the UK. In: Proceedings of the 87th Annual Conference of the Agricultural Economics Society, University of Warwick, United Kingdom. Banbury, UK: Agricultural Economics Society.

Taleb, N.N. 2012. Antifragile: Things that gain from disorder. Auckland: Penguin Books. 519 pp.

UMR. 2014. RMPP farmer segmentation report. Report prepared for the Red Meat Profit Partnership.

USDA. 2014. ERS food expenditure series. http:// www.ers.usda.gov/data-products/food-expenditures. aspx\#26654 Accessed 2 November 2015. 
